and no acetone or diacetic acid. The blood sugar at 2.30 p.m. was 0.3 per cent."

On enquiring into the past history, I was informed that the diabetes was discovered first about two years ago when he had had some injections of insulin. On the suggestion being made of this treatment being resumed, the man promptly bolted and we have seen no more of him.

We have here then a definite case of diabetic retinitis in one eye and typical haemorrhages in the other eye in a man of 22 years of age without obvious signs of diseased blood vessels and with a blood pressure of only $100 / 75$.

\title{
COMMUNIQUE
}

\section{International Association for the Prevention of Blindness}

The General Assembly of the International Association for the Prevention of Blindness was held in Paris, 2, Avenue Vélasquez, on Saturday, November 14, 1931, at 2 p.m., under the Chairmanship of Prof. de Lapersonne. The numerous personalities attending this meeting included: Mlle. de Teincey, representing H.R.H. the Duchess de Vendôme; M. Lévesque, representing the Minister of Health; M. Pigot, representing the Direction of Public Health; Military Intendant Bouscasse, representing General Pau, Chairman of the French Red Cross; Countess de Galard and Madame Barbier-Hugo, Presidents of two branches of the French Red Cross; Prof. Terrien and Dr. Morax (France); Dr. Pantaleoni, representing the League of Nations; Dr. Park Lewis, Vice-President of the International Association and of the National Society for the Prevention of Blindness, representing the United States; Prof. van Duyse (Belgium); Dr. MacCallan; Dr. and Mrs. Cridland (Great Britain); Prof. van der Hoeve (Netherlands); Prof. de Grosz (Hungary); Prof. Angelucci and Prof. Maggiore (Italy); Dr. Marquez (Spain); Dr. Zachert (Poland); Dr. Lossouarn, Chairman of the Chinese League for the Prevention of Blindness; Dr. Patry (Switzerland); etc.

PROF. DE LAPERSONNE outlined the work accomplished by the Association during the past year, laying particular emphasis on the formation of National Committees in the Argentine, Belgium, Brazil, France, Germany, Hungary, Italy, Mexico, Poland, Portugal and Spain. He pointed out that the composition of these Committees should be as representative as possible, the object of the Association being to reach all classes of the community. He reminded his audience of the great work done in America and Great 
Britain as regards sight-saving classes for the education of children with defective eyesight ; thanks to specialized methods of teaching, these children are given a chance of becoming normal members of the community. Dr. HUMBERT, Secretary General of the Association, had brought the subject before the Child-Welfare Committee of the League of Nations. Hundreds of Paris school children had been examined for ocular defects. The Association's Secretariat had acquired, for demonstration purposes, samples of the special material used in these classes. It was expected that a sightsaving class would soon be started in Paris.

In the absence of representatives from Germany and Argentina, Dr. A. ChURCHILL, Associate Secretary General, mentioned the formation of National Committees in these two countries.

Prof. van Duyse (Belgium), Dr. Coutela (France), Dr. Zachert (Poland), Prof. Maggiore (Italy), Dr. Marquez (Spain), Prof. de Grosz (Hungary), spoke on behalf of the newly constituted National Committees. Dr. Cridland (Great Britain) stated that he hoped a national organization for the prevention of blindness would soon be established in England.

Dr. HumberT, General Secretary of the Association, read a report on administrative matters during the year. On behalf of the Association he expressed his gratitude to those who had helped to promate its work and ideals; he mentioned especially the French Ministry of Public Health, the General Insurance Committee, and the National Society for the Prevention of Blindness, whose powerful and unfailing support had enabled the Association to make good progress. He also expressed his gratitude to Dr. Cridland, who had brought a generous contribution from an anonymous donor. He was glad to say that at the end of the fiscal year 1931 assets were almost three times as large as at the beginning of the year.

Dr. Humbert joined Prof. de Lapersonne in expressing his warmest thanks to Dr. Cridland and other delegates who had come to Paris on purpose to attend the Association's annual meeting.

Dr. Humbert added that the Association would be in a position to organize, in 1932, its Secretariat on an independent and autonomous basis, a step which would help to widen its sphere of influence.

DR. Coutela, General Secretary of the French Committee, submitted a report on "Present Legislation and Prophylaxis of Industrial Eye-accidents." $\mathrm{He}$ observed that this was a most important and up-to-date item in the Association's activities.

Any person suffering from an industrial eye-accident receives, while unfit for work, an indemnity. In France and most other countries this indemnity is equal to half the workman's salary, but it is only due if work is interrupted for more than four days. 
In other cases-known as minor injuries-the sufferer receives no indemnity. As approximately 80 per cent. of wounds of the eye come within the category of minor injuries; the great majority of eye accidents do not, as a rule, entitle the sufferer to any indemnity for cessation of work.

The result is that workmen with eye injuries, knowing they get no indemnity for such minor troubles, think twice before interrupting their work; the consequences of delayed or incompetent treatment are too often disastrous. The temporary disablement is prolonged and may even be followed by permanent disablement. Among the possible remedies to such a condition of affairs, the speaker suggested the awarding of a premium for immediate treatment, to the workman who had his eyes attended to at once. $\mathrm{He}$ observed that eye-injuries were different from all other industrial hazards and that it was necessary either to provide for special legislation or for a modification of existing Acts with regard to this category of accidents.

M. MaX Hermant, of the General Insurance Committee, seconded the speaker's conclusions and a resolution to this effect was unanimously adopted by the Assembly.

DR. CRIDLAND (Great Britain) then read a report on "The Value of a Complete Investigation of the Causes of Blindness as a First Step in Prevention." Everybody agreed that the first step in the prevention of a disease was a complete knowledge of its cause, and the knowledge of the cause of a disease could not be said to be complete unless one knew how frequent it was. We are already possessed of a knowledge of most of the causes of blindness, in spite of the fact that from time to time one still meets with rare cases in which one is unable to assign the actual cause of blindness, although the pathological changes in the eyes themselves which lead to this result may well be recognized.

We have not, however, a very definite knowledge in any country as to the exact frequency with which these causes occur, in other words we do not accurately know how common this or that cause of blindness is.

The ideal would be that one should have exact statistics as to the causes and frequency of blindness over the whole world. At prèsent such an ideal would be impossible, but something in that direction can be attempted. The question comes as to how even an attempt can be made.

Dr. Cridland then described the system used in Great Britain. Each blind person in the United Kingdom was in receipt of a pension, but before that pension could be obtained, it was necessary for the candidate for the pension to produce a certificate stating that he was "too blind to perform work for which eyesight is essential." 
By this means an opportunity was given, not only of knowing how many blind persons there are in the country, but, at the same time, of learning something of the cause of their blindness and its degree.

The Council of British Ophthalmologists had recently drawn up a report on the certification of blind persons, in which attention was drawn to the importance of the fact that the examination of a candidate for a blind pension should be made by an expert in ophthalmology if it was to be of real scientific value.

It was only in this way that a reliable census of the causes of blindness throughout any country could be obtained.

In conclusion, Dr. Cridland put forward the suggestion that at some future date the Association should consider the advisability of drawing up a schedule of the causes of blindness which might be used uniformly in all countries. The proposition was accepted after a speech to the same effect by DR. MARQUEZ (Spain).

Finally, DR. PARK LEWIS (United States), Vice-President of the Association, gave an address with cinematographic projections on "Certain Rare Forms of Cataract of a Parasitic Nature observed in Fish." He reminded his audience that at a conference in the City of Washington recently, a report was read by a representative of the Department of Public Health, in which he described the infestation of the native Indians by a filarial worm. An entire village of over seven hundred people as the result of this infestation had become to a greater or less degree blind. The infections were due to the transmission of the larvae from one to another by means of one of several varieties of gnats. An invasion of a parasite involving the eyes of such a large number of people had again called attention to the importance of parasites in relation to the eyes and while the subject of the present brief paper had no connexion with the filarial worm, the existence of other parasites in the eyes of living creatures to such an extent as to make the lens almost the normal habitat of certain variety of flukes could not fail to be of interest to ophthalmologists.

The speaker pointed out how these observations were a further inducement to extensive research in the treatment of cataract in human beings, an activity which came within the scope of blindness prevention.

In the course of the meeting the General Assembly unanimously re-elected its Executive Committee and staff, the latter being constituted as follows:

President: Prof. de Lapersonne (France).

Vice-President: Dr. Park Lewis (United States).

Secretary General: Dr. F. Humbert (Switzerland).

Treasurer General : M. R. Demachy.

Correspondent for the United States; L. H. Carris. Associate Secretary General: Dr. A. Churchill. 